\title{
Childbearing Decisions Of HIV Discordant Couples In Banjarmasin
}

\author{
Rizqy Amelia ${ }^{1 *}$ \\ ${ }^{1}$ Academy of Midwifery Sari Mulia, Banjarmasin \\ *rizqycutamelia@gmail.com
}

\author{
Antono Suryoputro ${ }^{2}$ \\ ${ }^{2}$ Faculty of Public Health Diponegoro University, Semarang \\ antono@undip.ac.id \\ Zahroh Shaluhiyah ${ }^{2}$ \\ ${ }^{2}$ Faculty of Public Health Diponegoro University, Semarang \\ zahro@undip.ac.id
}

\begin{abstract}
Objective: The purpose of this research is to describe the childbearing decisions in sero discordant couples.

Method: This research used a qualitative method with a case study research design. Total primary informants involved 10 informant couples, and triangulation informants involved 5 informants. The research instruments used are interview guidelines and in-depth interview and voice recorder.

Results: The results of the study showed 5 couples decided not to have children after one of them was infected with HIV, 3 couples decided to have more children and 2 couples who had no children decided to try and have children. There was no factor which influenced the couple's childbearing decisions such as family, doctor, counselor and colleagues.

Conclusion: Discordant couples decided not to have children after being infected with HIV.
\end{abstract}

Keywords: Childbearing Decisions, Discordant Couples, HIV, People Living With HIV/AIDS.

\section{INTRODUCTION}

At the end of the 20th century, the world of health was attacked by the emergence of a very dangerous and malignant disease, namely the disease of Acquired Immunodeficiency Syndrome (AIDS). Acquired Immunodeficiency Syndrome is an infectious disease caused by the virus Human Immunodeficiency Virus (HIV) The spread is very rapid throughout the world. Since becoming epidemic until 2011, HIV has infected more than 60 million men, women and children and who have AIDS has been close to 20 million in adults and children. Although the international community has responded to the HIV / AIDS pandemic, HIV continues to spread to more than 14,000 new infections daily. At present, AIDS is the leading cause of death in Africa and a quarter of the world [1].

Human Immunodeficiency Virus (HIV) is a virus attacking the immune system. The course of HIV infection in the body attacks the Cluster of Differentiation 4 (CD4) 
cells resulting in a decrease in the body's defense system. Continuous viral replication results in heavier immune system damage and is more susceptible to opportunistic infections (OIs) that will end in death [2].

The spread of HIV virus can occur through the exchange of needles, blood transfusions and sexual relations. Sexual behaviors that are part of the HIV / AIDS transmission have not been made as important in the community [3]. Transmission of HIV is currently very high: from injecting drug users (injections) (70.03\%), 3.1 million men buying sex, 230,000 women sex workers, 1.6 million married to men at high risk [4]. Half of the people with HIV and AIDS are women [5].

Every human being including PLHIV (People with HIV / AIDS) also have the same need that is the need to love/be loved. Relationship of love is a form of interpersonal attraction that becomes the basis of a marriage. Children are the next generation in the family, but for couples one of them with HIV it was very difficult. Being able to have sexual intercourse to have a child without safeguards can lead to the transmission of HIV to a partner or to a child conceived [6].

Systematic assessment of factors affecting children's willingness in people with HIV suggests factors that positively affect desire and intention to have children are younger, have little or no children, and have access to antiretroviral treatment (ART) [7].

South Kalimantan Province until March 2013 found 630 cases of which include, as many as 351 cases of HIV and 279 cases of AIDS. Percentage of cases by age, highest 20-29 years 38.9\%, 30-39 years $27.3 \%$, and $40-49$ years $9.7 \%$, percentage in men $38.3 \%$ and women $54.6 \%$. The highest number of cases of HIV / AIDS in direct and indirect female sex workers were 214 cases, followed by housewives and non-professional personnel, 66 cases, and 15 others [8].

In South Kalimantan Province there are 2 major referral hospitals for PMTCT located in the city of Banjarmasin, Ulin and Dr. H. Moh Anshari Saleh. From the results of preliminary studies conducted by researchers, in the city of Banjarmasin, there are 10 different seropositive couples. This couple routinely visited the VCT clinic located in RSUD Dr. H. Moh Anshari Saleh Banjarmasin while for RSUD Ulin Banjarmasin no couples have come. Of the 10 couples are couples who do not have children.

Based on the above background, the researchers intend to conduct research on the desire to have children in different seropositive couples in the city of Banjarmasin 2013, given the research has not been done.

\section{METHODS}

This research was conducted using qualitative research design which presented descriptively through an in-depth interview. The time approach of data collection in this research is cross-sectional, the interview is done on the research subject only once, the measurement of variables is done 
simultaneously. The population taken in this study coupled with valid status, in which one of them was HIV positive and the other was HIV negative / serodiscordant couples in Banjarmasin City, which amounted to 10 couples (20 persons). Informants in the study were taken in total sampling, ie selecting samples from all the existing population of 10 serodiscordant pairs (20 people). While the supporting/secondary informants for cross check are Counselor, Companion, and doctor at VCT clinic.

\section{RESULTS}

Table 1 Characteristics of key informants by age, education, and occupation

\begin{tabular}{|c|c|c|c|c|c|c|c|}
\hline \multirow{2}{*}{$\begin{array}{l}\mathrm{N} \\
\mathrm{O}\end{array}$} & \multirow{2}{*}{$\begin{array}{l}\text { Inform } \\
\text { ants' } \\
\text { Code }\end{array}$} & \multicolumn{2}{|c|}{ Ages } & \multicolumn{2}{|c|}{ Education } & \multicolumn{2}{|c|}{ Jobs } \\
\hline & & W & $\mathrm{P}$ & W & P & W & P \\
\hline 1 & PSG 1 & 46 & 23 & $\begin{array}{c}\text { Second } \\
\text { ary }\end{array}$ & High & $\begin{array}{c}\text { House } \\
\text { wife }\end{array}$ & Traders \\
\hline 2 & PSG 2 & 32 & 34 & $\begin{array}{c}\text { Second } \\
\text { ary }\end{array}$ & $\begin{array}{c}\text { Second } \\
\text { ary }\end{array}$ & $\begin{array}{c}\text { House } \\
\text { wife }\end{array}$ & Traders \\
\hline 3 & PSG 3 & 30 & 38 & High & High & $\begin{array}{l}\text { House } \\
\text { wife }\end{array}$ & Private \\
\hline 4 & PSG 4 & 28 & 31 & Grad & $\begin{array}{l}\text { Post } \\
\text { grad }\end{array}$ & $\begin{array}{c}\text { Teache } \\
\text { rs }\end{array}$ & Private \\
\hline
\end{tabular}

\begin{tabular}{lllllccc}
\hline 5 & PSG 5 & 30 & 34 & High & High & $\begin{array}{c}\text { House } \\
\text { wife }\end{array}$ & Private \\
\hline 6 & PSG 6 & 32 & 32 & High & $\begin{array}{c}\text { Under } \\
\text { grad }\end{array}$ & $\begin{array}{c}\text { House } \\
\text { wife }\end{array}$ & Private \\
\hline 7 & PSG 7 & 34 & 37 & High & High & $\begin{array}{c}\text { House } \\
\text { wife }\end{array}$ & Private \\
\hline 8 & PSG 8 & 34 & 37 & High & High & $\begin{array}{c}\text { Pedaga } \\
\text { ng }\end{array}$ & Private \\
& & & & & & & \\
\hline 9 & PSG 9 & 32 & 35 & High & Underg & IRT & Sailor \\
& & & & & rad & & \\
\hline 1 & $\begin{array}{l}\text { PSG } \\
10\end{array}$ & 37 & 35 & High & S1 & IRT & Sailor \\
\hline
\end{tabular}

The main characteristic of the key informants by age was that the highest was 46 years and the lowest was 23 years, and the highest education for primary informants was Strata 3 and the lowest was junior high. The types of key informant jobs vary such as traders, private employees, security guards and sailors.

Table 2 characteristics of key informants by age at marriage, marriage age, number of marriages and number of children.

\begin{tabular}{|c|c|c|c|c|c|c|c|c|}
\hline \multirow{2}{*}{ No } & \multirow[t]{2}{*}{$\begin{array}{c}\text { Informa } \\
\text { nts' } \\
\text { Codes }\end{array}$} & \multicolumn{2}{|c|}{$\begin{array}{c}\text { Age when } \\
\text { Married }\end{array}$} & \multirow{2}{*}{$\begin{array}{c}\text { Age } \\
\text { before } \\
\text { marriage }\end{array}$} & \multicolumn{2}{|c|}{$\begin{array}{c}\text { Numbe } \\
\text { r of } \\
\text { marria } \\
\text { ges }\end{array}$} & \multicolumn{2}{|c|}{$\begin{array}{c}\text { Numbe } \\
\text { r of } \\
\text { childre } \\
\text { n }\end{array}$} \\
\hline & & $\mathrm{W}$ & $\mathrm{P}$ & & $\mathrm{W}$ & $\mathrm{P}$ & $\mathrm{W}$ & $\mathrm{P}$ \\
\hline 1 & PSG 1 & 45 & 22 & 1 years & 2 & 1 & 3 & 0 \\
\hline 2 & PSG 2 & 30 & 32 & 2 years & 1 & 2 & 1 & 3 \\
\hline 3 & PSG 3 & 27 & 35 & 3 years & 2 & 2 & 3 & 3 \\
\hline 4 & PSG 4 & 26 & 29 & 2 years & 1 & 1 & 1 & 1 \\
\hline 5 & PSG 5 & 28 & 32 & 1,5 years & 2 & 2 & 0 & 0 \\
\hline 6 & PSG 6 & 27 & 27 & 5 years & 1 & 1 & 1 & 1 \\
\hline 7 & PSG 7 & 32 & 35 & 2 tahun & 1 & 2 & 1 & 1 \\
\hline 8 & PSG 8 & 27 & 30 & 7 years & 1 & 2 & 1 & 1 \\
\hline 9 & PSG 9 & 26 & 29 & 6 tahun & 1 & 1 & 2 & 2 \\
\hline 10 & PSG10 & 32 & 30 & 5 years & 2 & 2 & 2 & \\
\hline
\end{tabular}

The main characteristic of the informant by age when the oldest marriage is 45 years and the youngest is 22 years old, according to the age of the longest marriage is 7 years and the latest one year, according to the number of marriage average married twice and according to the number of children most is 3 people. 
Table 3 Characteristics of informant triangulation by age, last education, and occupation

\begin{tabular}{ccccc}
\hline No & & Ages & $\begin{array}{c}\text { Last } \\
\text { education }\end{array}$ & Pekerjaan \\
\hline 1 & D1 & 34 & S1 & Dokter \\
\hline 2 & D2 & 29 & S1 & Dokter \\
\hline 3 & P1 & 29 & SMA & Swasta \\
\hline 4 & P2 & 27 & D3 & Swasta \\
\hline 5 & K & 38 & D3 & Konselor \\
& & & & RS
\end{tabular}

The characteristics of the informant triangulation in this study according to the age of the oldest are 38 years and the youngest is 27 years old, the highest education is Strata 1 and the lowest Diploma 3. The work of the triangulation informants is doctors, counselors, and counselors.

Table 4 The decision of having a child for serodiscordant partner

\begin{tabular}{|c|c|c|}
\hline \multirow[t]{2}{*}{$\begin{array}{l}\text { Decision to } \\
\text { have } \\
\text { children }\end{array}$} & $\begin{array}{l}\text { Couples of } \\
\text { Sero } \\
\text { Discordant } \\
\text { Females (+) } \\
\text { Males (-) }\end{array}$ & $\begin{array}{c}\text { Couples of Sero } \\
\text { Discordant } \\
\text { Males (+) } \\
\text { Females (-) }\end{array}$ \\
\hline & $\begin{array}{l}\text { As many as } \\
\text { four positive } \\
\text { women state } \\
\text { to have } \\
\text { children } \\
\text { while three } \\
\text { states they } \\
\text { don't want } \\
\text { to have } \\
\text { children } \\
\text { anymore. } \\
\text { Two positive } \\
\text { women state } \\
\text { that they } \\
\text { have done } \\
\text { something in } \\
\text { order to be } \\
\text { pregnant in a } \\
\text { short time } \\
\text { something to } \\
\text { prevent the } \\
\text { transmission } \\
\text { by taking } \\
\text { ART regularly. } \\
\text { The three } \\
\text { women } \\
\text { refuse to }\end{array}$ & $\begin{array}{l}\text { As many as two } \\
\text { positive men } \\
\text { state they don't } \\
\text { want to have } \\
\text { children. Only } \\
\text { one positive } \\
\text { man states he } \\
\text { wants. } \\
\text { The positive } \\
\text { man has done } \\
\text { something to } \\
\text { prevent } \\
\text { transmission to } \\
\text { the partner by } \\
\text { taking ART } \\
\text { regularly. } \\
\text { Two men refuse } \\
\text { to have children } \\
\text { because they } \\
\text { want to focus on } \\
\text { the children they } \\
\text { already have. }\end{array}$ \\
\hline
\end{tabular}

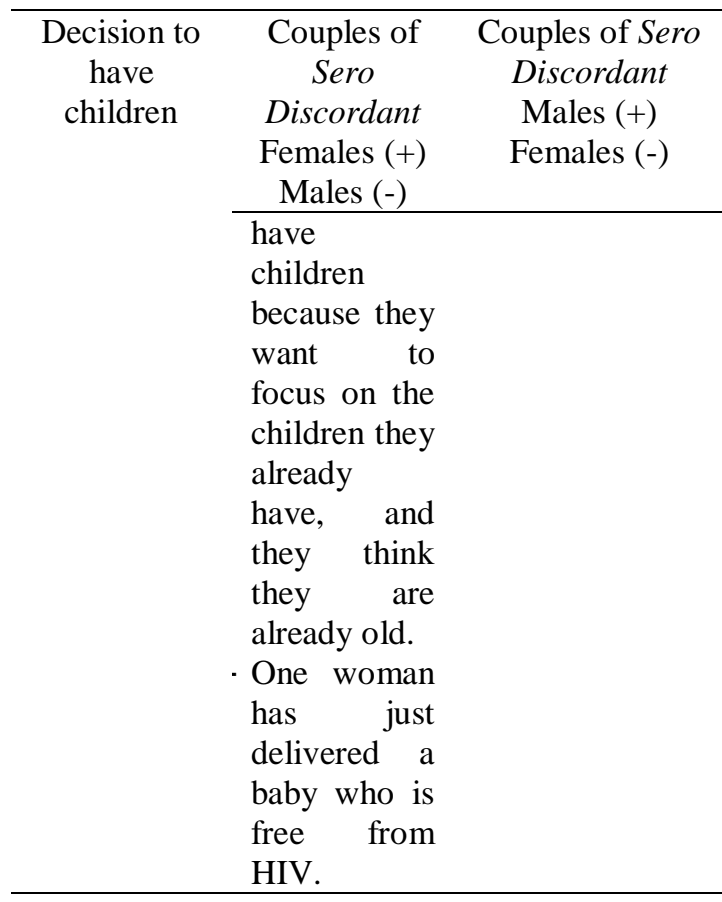

The results of the study concluded that 5 serodiscordant couples said they wanted to have a child even if one had been HIV-infected, one had just had a child. Couples who want to have more children than women are positive this is because of the couple is not at all have children and couples want to have offspring as a successor. From 5 couples who want to have children 4 from positive women and 1 from positive men. Couples who are not yet at all have children from two positive women, 2 positive women are indeed very eager to have children due to fear of no successor offspring. 
Table 5 Summary of Research Results About Attitudes to Childhood Meaning

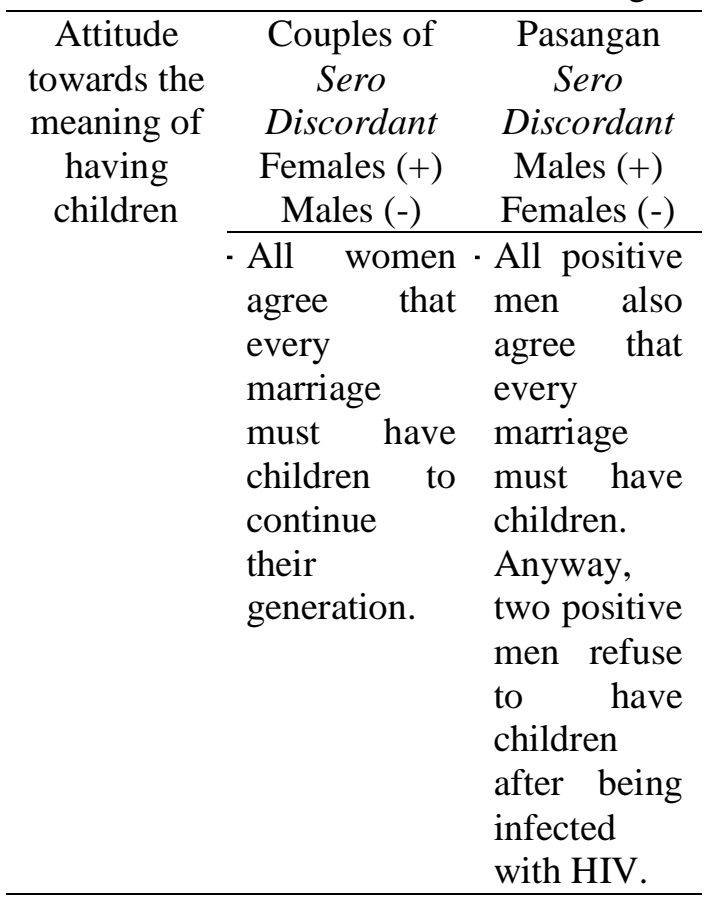

Based on the results of the study can be concluded that the value of children for a serodiscordant couple is something important grace from God who became the hereditary descendants as the hope that someday will boast the couple. There is no difference in the value of the child to the spouse either from positive women or positive men. Children are also an asset for couples because couples assume when an old child there will be a couple who care for the couple.
Table 6 Summary of Research Results About Influencing Factors for Children

\begin{tabular}{|c|c|c|}
\hline \multirow[t]{2}{*}{$\begin{array}{l}\text { Knowledge } \\
\text { about factors } \\
\text { influencing } \\
\text { to have } \\
\text { children }\end{array}$} & $\begin{array}{c}\text { Couples } \\
\text { with Sero } \\
\text { Discorda } \\
n t \\
\text { Females } \\
(+) \\
\text { Males (-) }\end{array}$ & $\begin{array}{l}\text { Couples with Sero } \\
\text { Discordant Males } \\
(+) \text { Females (-) }\end{array}$ \\
\hline & $\begin{array}{l}\text { All } \\
\text { positive } \\
\text { women } \\
\text { state that } \\
\text { nobody } \\
\text { influence } \\
\text { s them to } \\
\text { have } \\
\text { children. }\end{array}$ & $\begin{array}{l}\text { Just like positive } \\
\text { women, positive } \\
\text { men have nobody } \\
\text { influences them to } \\
\text { have children. } \\
\text { The decision is } \\
\text { their own. }\end{array}$ \\
\hline
\end{tabular}

\section{DISCUSSION}

Characteristics of primary informants in this study, the age range of primary informants between 23-46 years. In addition, based on the characteristics of other informants, it was shown that 10 primary informants were female as a wife and 10 other primary informants were male as a husband.

Based on the last level of education from primary informants, the lowest level of education is Junior High School and the highest is Strata 3. Based on the average job as the wife of the informant is only a housewife, there are only two who works as a trader and a teacher, while for husbands have diverse occupations such as traders, security guards, private and sailors.

Characteristics of secondary informants/triangulation through interviews, it is known that the age range of informants cross-checks between 27-38 years. Meanwhile, based on the characteristics of gender, 2 informants were identified cross 
check male and 3 female sex. Characteristics Educational level of informants cross-check, 1 of which are high school graduates, 2 come from college and 2 from diploma.

Based on the results of the study on ten couples who became informants of five couples consisting of three positive women and two positive men refused to have children after one of the infected with HIV, the reason the couple informants already have a previous child, then for fear of children contracting and feel themselves is too old to have more children.

Four other couples consisting of three positive women and one positive male said they wanted to have a child even though one of them was infected with HIV but for the time being yet, the informant was still preparing and waiting for the older child first. And one positive female partner has just had a child who was pregnant and was born after knowing one was infected with HIV. People with HIV have the same rights as others in this regard. Obviously, there are several other factors to consider.

The decision to have children should be discussed with the couple. It is recommended that this discussion is done with the help of doctors and trained counselors. But, ultimately, the decision is the right of the couple. To make the best decision, must have the correct information. [9]

The tendency of HIV infection in Women and Children Increases, therefore, necessary efforts to prevent HIV infection in women, as well as to prevent the transmission of HIV from pregnant women to infants is PMTCT (Prevention of Mother to Child HIV Transmission). [10]

People with HIV have the same rights as others in having children. Obviously, there are several other factors to consider. The decision to get a child should be discussed with the couple. [11]

Based on the results of the research with in-depth interviews with 10 couples of informants about the couple's attitude to have children is according to 10 pairs of informants they all consider the meaning of having children in a marriage relationship is something important. They consider the child to be the successor of the offspring, the child also as a priceless gift and the child is a hope for the parents. Although informants suffer from HIV informants and couples have equal rights in having children.

The results of the study to 10 couples informants about taking ART drugs for prevention of transmission of children when deciding to have children is according to 4 couples consisting of 3 positive women and 1 positive men who decided to have and add children already regularly taking his ART.

Every family generally crave children, because the child is the hope or the ideals of a marriage. It can not be denied that the child has a certain value for parents. Based on the results of the research with in-depth 
interviews with 10 couples informants about the value of children for couples submitted that according to 10 couples informants agree that having children is something very important. Informants assume that the child is the hereditary. The child is also a hope, the child of all things which is a gift from God.

\section{CONCLUSION}

Based on the results of research on the factors that affect to have children by their partners, the results obtained that 10 couples say there is no interplay to have children. Informants always make decisions together in the affairs of children and others. There was one spouse whose husband had influenced his wife to have another child, but after discussing it with his wife and wife, he thought he was too old to have a child and agreed not to have any more children.

The results of this study are in accordance with the narrative informant triangulation which conveyed that doctors only provide advice and support not to influence and provide the client's decision to have children.

\section{REFERENCES}

[1] WHO. Global HIV/AIDS Respone Epidemic. unaids; 2011 [cited 201317 April]; Available from: http://www.unaids.org/en/media/unaids/ contentassets/documents/unaidspublicat ion/2011/20111130uareporten.pdf.
[2] Brunner\&Suddarth. Keperawatan Medikal Bedah. Jakarta: EGC; 2011.

[3] Sugiyati S. Refleksi Hari AIDS 1 Desember HIV/AIDS dan PMS.(online). 2008 [cited 201318 April]; Available from: http://www.pelita.or.id/baca/php?id=40 361.

[4] DINKES C-F. Modul Pelatihan deteksi dini pencegahan dan penanggulangan HIV dan AIDS pada perempuan kesehatan masyarakat. Bandung: DINKES; 2011.

[5] UNAIDS. Report on the Global AIDS Epidemic. 2008 [cited 201323 Nopember]; Available from: http://www.unaids.org/en/KnowladgeCe ntre/HIV/Data/Global/Report/2008.

[6] Yayasan Spiritia. Peningkatan risiko penularan HIV pada pasangan serodiskordan yang ingin memiliki anak. 2012 [cited 201317 April]; Available from: http://spiritia.or.id/pdf/newspdf/php?nw $\underline{\mathrm{no}=1578}$

[7] Yayasan Spiritia. Lembar Informasi tentang HIV/AIDS 2012. Available from:

http://www.spiritia.or.id/li/pdf/LIKompl et.pdf.

[8] Dinkes Provinsi Kalsel. Laporan Perkembangan Kasus HIV/AIDS, Triwulan I tahun 2013. Banjarmasin: 201322 Juli 2013. Report No.: Contract No.: 443/2880-P2PL/Din.Kes.

[9] Depkes RI. Pedoman Nasional Pencegahan Penularan HIV dari Ibu ke Bayi. In: Depkes RI, editor. Jakarta 2010

[10] Thornton A, Romanelli F, Collins J. Reproduction decision-making for couples affected by HIV: a review of the literature. Topical HIV Medicine 2004;12(2):61-67.

[11] Barreiro P, Duerr A, Beckerman K, et al. Reproductive options for HIVdiscordant couples AIDS Review 2006;8(3):158-70. 